\title{
Effects of Media Composition and Auxins on Adventitious Rooting of Bienertia sinuspersici Cuttings
}

\author{
Jennifer Anne Northmore, Marie Leung, Simon Dich Xung Chuong* \\ Department of Biology, University of Waterloo, Waterloo, Canada \\ Email: schuong@uwaterloo.ca
}

Received 3 September 2015; accepted 9 October 2015; published 12 October 2015

Copyright (C) 2015 by authors and Scientific Research Publishing Inc.

This work is licensed under the Creative Commons Attribution International License (CC BY). http://creativecommons.org/licenses/by/4.0/

(c) (i) Open Access

\section{Abstract}

An efficient in vitro method for rapid vegetative propagation of Bienertia sinuspersici, one of four terrestrial species of family Chenopodiaceae capable of performing $\mathrm{C}_{4}$ photosynthesis within a single cell, was developed. Cuttings of $B$. sinuspersici were used to examine the effects of Murashige and Skoog (MS) media strength and auxins on adventitious root formation. Half-strength MS medium was determined to be ideal for adventitious root formation in Bienertia cuttings. Although cuttings cultured in medium containing $5.0 \mathrm{mg} / \mathrm{L} \alpha$-naphthalene acetic acid (NAA) promoted the highest number of adventitious roots, cuttings cultured in medium supplemented with $1.0 \mathrm{mg} / \mathrm{L}$ indole-3-butyric acid (IBA) produced the longest adventitious roots and had the highest survival rate upon transplanting to soil. Histological analysis revealed variations in the root anatomy generated by the various auxins which may affect adventitious root formation and subsequent establishment of cuttings in soil. Overall, the established procedure provides a simple and cost-effective means for the rapid propagation of the single-cell $C_{4}$ species $B$. sinuspersici.

\section{Keywords}

Bienertia sinuspersici, Single-Cell $\mathrm{C}_{4}$ Photosynthesis, MS Media, Auxins, Adventitious Roots

\section{Introduction}

Bienertia sinuspersici, a halophytic shrub-like member of the Chenopodiaceae family indigenous to Southeast Asia, was discovered to possess a novel form of single-cell $\mathrm{C}_{4}$ photosynthesis [1]. In this species, key photosynthetic enzymes and organelles such as chloroplasts and mitochondria are partitioned into two intracellular cy-

\footnotetext{
"Corresponding author.
} 
toplasmic compartments within individual chlorenchyma cells achieving the equivalent functions of the mesophyll and bundle sheath cells in the Kranz-type $\mathrm{C}_{4}$ plants [1]-[3]. The unique single-cell $\mathrm{C}_{4}$ photosynthetic mechanism of $B$. sinuspersici has altered our understanding of how plants have evolved innovative solutions to improve photosynthetic efficiency. This discovery has also provided plant researchers with possibility of engineering $C_{3}$ crops to utilize the more efficient $C_{4}$ pathway to improve yields under extreme environmental conditions.

Conventional propagation of $B$. sinuspersici from seed-derived plants is insufficient in generating adequate plant material for basic cellular and molecular research purposes mainly due to its slow growth process. In addition, the limited seed stock and low seed production and viability further discourage its propagation via this method. Plants produced through vegetative asexual propagation are genetically identical to the parent and therefore contain the same desired phenotypes [4]. Moreover, there is an urgent need to maintain a healthy living stock so that sufficient material of this fascinating species can be rapidly generated for various research experiments. Therefore, an in vitro propagating method was established for B. sinuspersici using cuttings from seedderived plants.

Vegetative asexual propagation provides a means for high-frequency replication of plant material through the use of cuttings. Vegetative asexual propagation relies on branches of an established mature plant as the starting material for creating a genetically identical daughter plant and that there is a sizeable increase in propagation efficiency as compared to growing plants from seeds. Adventitious root induction of cuttings has been established and employed as a routine method of propagating many plants for their agricultural, horticultural, industrial, or pharmaceutical properties [5] [6]. Vegetative asexual propagation is particularly advantageous for rare or attractive plants where a specific trait like flower size or colour is desired in daughter plants, which is of particular important value in the horticulture industry [4]. For example, vegetative cuttings are used to reproduce many grape vines to maintain a single cultivar with a particular appearance, and flavour within a vineyard [7]. Moreover, vegetative propagation is efficient because it reduces the amount of time required for seedling establishment and a large number of healthy living stock plants can be produced rapidly from a small amount of available original plant material. Rooted cuttings can also serve as potential rootstocks for grafting experiments for plant species that are recalcitrant to adventitious root induction process or for multiplication of transgenic shoots [8] [9]. In addition, findings on nutrient requirements and effects of auxins on rooting of $B$. sinuspersici cuttings may provide valuable insight into factors that influence the in vitro regeneration process.

In general, root induction can be initiated by adding an auxin to the growth medium [10]. The role of auxins in organ formation, especially root induction and adventitious root formation, has been invaluable in the field of plant tissue culture [4]. Rooting is primarily regulated by a high auxin to cytokinin ratio, therefore root formation can generally be induced by adding an auxin to the growth medium [10]. Common auxins used for root induction in vitro include 2,4 dichlorophenoxyacetic acid (2,4-D), indole-3-acetic acid (IAA), indole-3-butyric acid (IBA), and $\alpha$-naphthalene acetic acid (NAA).

Except for two reports on the regeneration using indirect organogenesis as well as direct shoot micropropagation [11] [12], no additional in vitro studies on the rapid vegetative propagation of $B$. sinuspersici have been documented. The purpose of this study is to examine the effects of Murashige and Skoog (MS) basal medium strengths and various auxins on the induction of adventitious roots in B. sinuspersici cuttings so that an efficient and rapid method for vegetative propagation of massive plant material can be established.

\section{Materials and Methods}

\subsection{Plant Materials}

Cuttings ( 5 - $8 \mathrm{~cm}$ ) were obtained from six independent 6- to 8-month old Bienertia sinuspersici plants derived from seeds grown in a growth chamber (model GCW-15H; Environmental Growth Chambers, Ohio, USA) under $350 \mu \mathrm{mol} / \mathrm{m}^{2} / \mathrm{s}^{1}$ with a $14 \mathrm{~h} / 10 \mathrm{~h}$ light/dark photoperiod and a $25 / 18^{\circ} \mathrm{C}$ day/night temperature regime. Plants were fertilized with Miracle-Gro (24-8-16) and $150 \mathrm{mM} \mathrm{NaCl}$ once a week and watered when needed. Leaves were excised from the bottom $3 \mathrm{~cm}$ of the stem before cuttings were surface sterilized with $10 \%(\mathrm{v} / \mathrm{v})$ bleach for 10 min and rinsed three times with sterile $\mathrm{dH}_{2} \mathrm{O}$ for 5 min each.

\subsection{Root Induction and Greenhouse Acclimation}

Four sterilized cuttings were placed in each Magenta box containing various concentrations of MS medium 
(quarter-, half-, three quarter-, or full-strength). Full strength MS media consisted of $4.32 \mathrm{~g} / \mathrm{L}$ MS basal medium with Gamborg's vitamins (Sigma-Aldrich, Ontario, Canada), 1.96 g/L MES, 30 g/L sucrose, and 7 g/L agar, adjusted to $\mathrm{pH} 5.8$ and autoclaved at $121^{\circ} \mathrm{C}, 1.1 \mathrm{~kg} / \mathrm{cm}^{2}$ for $30 \mathrm{~min}$. After autoclaving, the media was allowed to cool to approximately $60^{\circ} \mathrm{C}$ before hormones were added. All plant hormones were purchased from Sigma-Aldrich and prepared as $1 \mathrm{mg} / \mathrm{ml}$ working stock solutions in hydrochloric acid, filter sterilized through a $0.2 \mu \mathrm{m}$ filter, and stored at $-20^{\circ} \mathrm{C}$.

Root induction of cuttings was also performed on half-strength MS medium supplemented with auxins (IAA, IBA, NAA, and 2,4-D) at 0.5, 1.0, 2.5, and $5.0 \mathrm{mg} / \mathrm{L}$. Cuttings were maintained in a growth chamber (Percival Scientific, Iowa, USA) with a $14 \mathrm{~h} / 10 \mathrm{~h}$ light/dark photoperiod at $22^{\circ} \mathrm{C}$ under $25 \mu \mathrm{mol} / \mathrm{m}^{2} / \mathrm{s}^{1}$. Rooted cuttings were carefully removed from the agar, gently washed in water, photographed, and the number and length of roots was recorded for each plant before transplanting to $10 \mathrm{~cm}$ pot containing Sunshine mix \#4 potting soil. Transplanted cuttings were maintained in a humidifying dome and gradually acclimatized to greenhouse conditions. The survival rate of transplanted cuttings was determined 3 weeks after the plants were completely uncovered and transferred to greenhouse conditions.

\subsection{Histological Analysis}

Root samples were fixed in 2\% (v/v) paraformaldehyde and 2\% (v/v) glutaraldehyde (Electron Microscopy Sciences [EMS], Pennsylvania, USA) in $50 \mathrm{mM}$ PIPES buffer, $\mathrm{pH} 7.2$ overnight at $4^{\circ} \mathrm{C}$, dehydrated with a graded ethanol series and gradually infiltrated with increasing concentrations of London Resin White (LR white; EMS, Pennsylvania, USA) acrylic resin. Sections $(1 \mu \mathrm{m})$ were prepared on a Reichert Ultracut E ultramicrotome (Reichert-Jung, Heidelberg, Germany), dried onto glass slides, and stained with $0.1 \%$ (w/v) Toluidine blue (TBO) (Sigma-Aldrich, Ontario, Canada). Images were captured using a cooled CCD camera (Retiga 1350 Exi Fast, Qimaging, British Columbia, Canada) and OpenLab (OpenLab, Ontario, Canada) imaging software. Image processing was performed using Adobe Photoshop CS (Adobe, California, USA).

\subsection{Statistical Analysis}

Each treatment consisted of twenty cuttings and the experiment was repeated at least three times. To assess the treatment differences, the results were analyzed by analysis of variance (ANOVA) and the variation among means were analyzed by Duncan's multiple range test at $\mathrm{P}<0.05$.

\section{Results}

\subsection{Effect of MS Concentration on Adventitious Rooting of Cuttings}

After 3 weeks of culture, adventitious roots were observed on the cuttings in all treatments (Table 1). There was no significant difference in the number of roots formed among the different MS-containing media, however the presence of half- or three quarter-strength MS basal salts in the medium improved root length significantly. The highest number of roots were observed in the treatment containing quarter-strength MS, while three-quarter-strength MS produced the longest roots. Although media containing half-strength MS produced a compromise between root length and number, this treatment had the highest survival rate after transplantation. Therefore, half-strength MS was used for subsequent experiments to examine the effect of auxins on adventitious

Table 1. Effect of MS concentration on adventitious root induction from B. sinuspersici cuttings after 3 weeks of culture.

\begin{tabular}{cccc}
\hline MS strength & Number of roots/cutting & Root length $(\mathrm{cm})$ & Survival rate $(\%)$ \\
\hline 0 & $5.9 \pm 2.5^{\mathrm{a}}$ & $3.2 \pm 1.9^{\mathrm{b}}$ & $41.4 \pm 12.0^{\mathrm{c}}$ \\
$1 / 4$ & $10.0 \pm 2.2^{\mathrm{a}}$ & $3.6 \pm 2.4^{\mathrm{b}}$ & $100^{\mathrm{a}}$ \\
$1 / 2$ & $9.4 \pm 3.0^{\mathrm{a}}$ & $6.3 \pm 3.8^{\mathrm{ab}}$ & $100^{\mathrm{a}}$ \\
$3 / 4$ & $6.0 \pm 3.1^{\mathrm{a}}$ & $9.8 \pm 2.8^{\mathrm{a}}$ & $71.4 \pm 9.0^{\mathrm{b}}$ \\
1 & $8.6 \pm 2.4^{\mathrm{a}}$ & $4.9 \pm 2.2^{\mathrm{ab}}$ & $71.4 \pm 11.0^{\mathrm{b}}$ \\
\hline
\end{tabular}

Results represent means \pm standard error mean (SEM) of three replicated experiments. For each column, numbers followed by the same letter are not significantly different using Duncan's Multiple Range Test, $\mathrm{P}<0.05$. 
roots formation. Rooted cuttings were removed from media, transplanted to soil, and acclimatized to greenhouse conditions (Figure 1). Overall, the survival rates of rooted cuttings from MS treatments were significantly higher than that of the control (0 MS) with the quarter- and half-strength MS treatments providing the best rates (Table 1).

\subsection{Effects of Auxin on Adventitious Rooting of Cuttings}

After three weeks in culture, significant differences were found between many of the treatments cultured on half-strength MS media supplemented with various auxins (2,4-D, IAA, IBA, and NAA) (Table 2). Table 2 shows that the addition of $1 \mathrm{mg} / \mathrm{L}$ IBA was most successful at inducing adventitious roots from cuttings. The addition of IBA to the growth medium produced several long roots with many lateral roots and root hairs (Figure 2(c)). These IBA-rooted cuttings had the highest survival rate after transplanting to soil. In general, cuttings

Table 2. Effect of different auxins on adventitious root induction from B. sinuspersici cuttings after 3 weeks of culture.

\begin{tabular}{|c|c|c|c|c|}
\hline Hormone & Concentration (mg/L) & Number of roots/cutting & Root length (cm) & Survival rate (\%) \\
\hline $2,4-\mathrm{D}$ & $\begin{array}{c}0 \\
0.5 \\
1.0 \\
2.5 \\
5.0\end{array}$ & $\begin{array}{l}11.8 \pm 2.2^{\mathrm{d}} \\
10.4 \pm 3.2^{\mathrm{d}} \\
13.4 \pm 3.7^{\mathrm{c}} \\
5.6 \pm 2.7^{\mathrm{de}} \\
1.7 \pm 0.7^{\mathrm{e}}\end{array}$ & $\begin{array}{c}16.4 \pm 7.4^{\mathrm{ab}} \\
1.8 \pm 0.5^{\mathrm{c}} \\
2.0 \pm 0.7^{\mathrm{c}} \\
1.4 \pm 0.5^{\mathrm{c}} \\
0.5 \pm 0.4^{\mathrm{e}}\end{array}$ & $\begin{array}{c}77.8 \pm 10.1^{\mathrm{b}} \\
0.0^{\mathrm{e}} \\
50.0 \pm 8.0^{\mathrm{c}} \\
25.0 \pm 7.6^{\mathrm{d}} \\
17.0 \pm 4.0^{\mathrm{d}}\end{array}$ \\
\hline IAA & $\begin{array}{l}0.5 \\
1.0 \\
2.5 \\
5.0\end{array}$ & $\begin{array}{l}21.0 \pm 5.0^{\mathrm{b}} \\
23.1 \pm 4.1^{\mathrm{b}} \\
28.3 \pm 8.2^{\mathrm{b}} \\
21.8 \pm 7.6^{\mathrm{bc}}\end{array}$ & $\begin{array}{l}2.7 \pm 0.5^{c} \\
3.4 \pm 0.6^{c} \\
2.9 \pm 0.6^{c} \\
3.4 \pm 0.6^{c}\end{array}$ & $\begin{array}{c}50.0 \pm 10.4^{\mathrm{c}} \\
49.5 \pm 9.4^{\mathrm{c}} \\
83 \pm 8.7^{\mathrm{b}} \\
17.0 \pm 5.4^{\mathrm{d}}\end{array}$ \\
\hline IBA & $\begin{array}{l}0.5 \\
1.0 \\
2.5 \\
5.0\end{array}$ & $\begin{array}{c}14.3 \pm 1.9^{\mathrm{c}} \\
9.1 \pm 1.6^{\mathrm{d}} \\
10.7 \pm 0.3^{\mathrm{d}} \\
14.8 \pm 3.7^{\mathrm{bc}}\end{array}$ & $\begin{array}{l}27.3 \pm 6.1^{\mathrm{a}} \\
29.4 \pm 7.0^{\mathrm{a}} \\
25.3 \pm 6.7^{\mathrm{a}} \\
15.0 \pm 5.6^{\mathrm{ab}}\end{array}$ & $\begin{array}{c}83.0 \pm 5.4^{\mathrm{b}} \\
100^{\mathrm{a}} \\
100^{\mathrm{a}} \\
100^{\mathrm{a}}\end{array}$ \\
\hline NAA & $\begin{array}{l}0.5 \\
1.0 \\
2.5 \\
5.0\end{array}$ & $\begin{array}{l}15.5 \pm 4.4^{\mathrm{bc}} \\
19.4 \pm 6.0^{\mathrm{bc}} \\
16.5 \pm 8.4^{\mathrm{bc}} \\
44.2 \pm 13.6^{\mathrm{a}}\end{array}$ & $\begin{array}{c}6.7 \pm 2.6^{\mathrm{b}} \\
6.1 \pm 3.0^{\mathrm{b}} \\
6.4 \pm 4.2^{\mathrm{bc}} \\
1.3 \pm 0.4^{\mathrm{d}}\end{array}$ & $\begin{array}{c}100^{\mathrm{a}} \\
50.0 \pm 7.3^{\mathrm{c}} \\
66.0 \pm 5.8^{\mathrm{bc}} \\
77.3 \pm 9.3^{\mathrm{b}}\end{array}$ \\
\hline
\end{tabular}

Results represent means \pm standard error mean (SEM) of three replicated experiments. For each column, numbers followed by the same letter are not significantly different using Duncan's Multiple Range Test, $\mathrm{P}<0.05$.
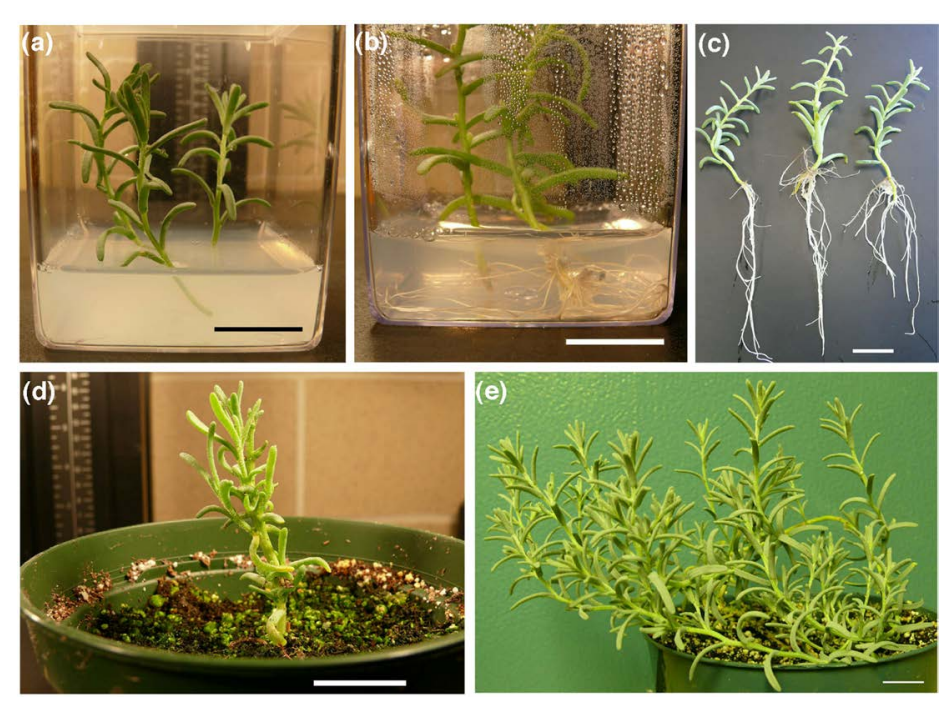

Figure 1. Induction of adventitious roots and plant regeneration from cuttings of Bienertia sinuspersici. (a) Sterilized cuttings of B. sinuspersici culture in rooting medium. (b) Cuttings with adventitious roots after 3 weeks of culture. (c) Cuttings with many long healthy roots from $1 \mathrm{mg} / \mathrm{L}$ IBA treatment. (d) Transplanted cutting fully acclimated to greenhouse conditions after 3 weeks. (e) B. sinuspersici plant derived from cuttings after 3 months in the greenhouse. Scale bars $=2 \mathrm{~cm}$. 

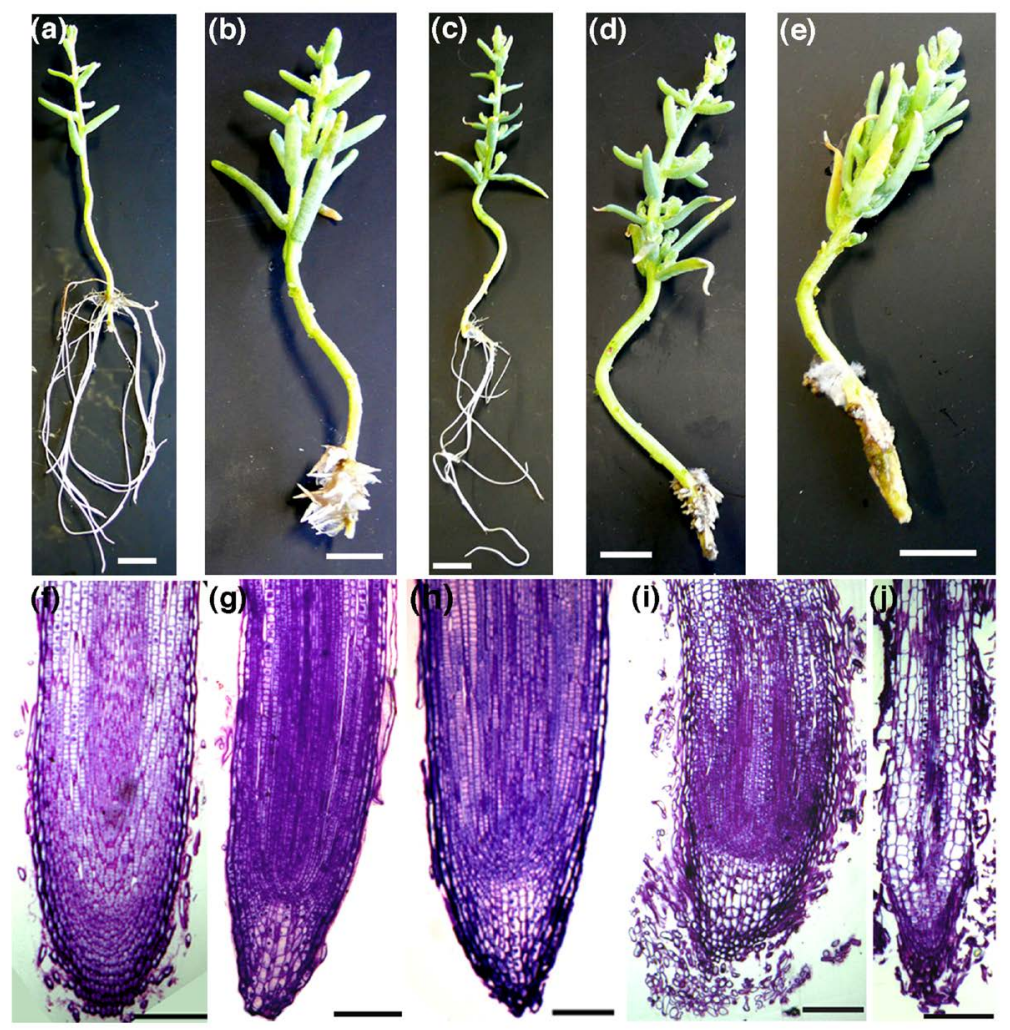

Figure 2. Effect of auxins on adventitious root formation and root anatomy in cuttings of Bienertia sinuspersici. Histological analysis of root morphology and anatomy. Cuttings were rooted on (a) and (f) hormone-free medium and medium supplemented with (b) and (g) IAA, (c) and (h) IBA, (d) and (i) NAA, or (e) and (j) 2,4-D. Scale bars $=2 \mathrm{~cm}$.

with longer healthy roots were more predisposed to survival after transplantation compared to those with many short roots. For example, cuttings that were cultured on $5 \mathrm{mg} / \mathrm{L}$ NAA produced the highest number of roots, but the plants did not survive in soil, whereas cuttings treated with IBA produced fewer, longer roots and had higher survival rates after transplantation (Table 2). 2,4-D treatment produced a few short, feather-like aerial roots on cuttings just above the agar surface (Figure 2(e)). Similarly, cuttings cultured on media supplemented with IAA formed clusters of many short and thick roots at the base (Figure 2(b)). IAA-rooted cuttings demonstrated moderate success upon transplanting, due to the quantity of roots and the stability provided by the compact root structure. However, the cluster of roots made it difficult to remove the agar without causing physical damage. Cuttings cultured on media containing NAA developed many short and stubby root protrusions that were accompanied by a few feathery roots above the surface of the media similar to those observed in the 2,4-D treatment (Figure 2(d)). These cuttings with poorly developed roots were unable to establish in soil. It was generally observed that cuttings with many short roots had lower survival rates after transplantation, compared to those with fewer but longer roots. Even though cuttings cultured on $1 \mathrm{mg} / \mathrm{L}$ IBA produced fewer roots than some of the other treatments, the roots were the longest and had the highest rate of survival after transplanting. Roots induced by IBA appeared much healthier and more viable than those produced in the hormone-free media. In addition, high survival rates after transplantation to soil further suggest IBA as the favorable candidate for in vitro root induction.

The root anatomy was analyzed to examine the effect of auxins on the growth and development of adventitious roots in B. sinuspersici. Longitudinal sections of root tips on hormone-free media showed a thin root cap surrounding the root apical meristem that overlaps with the zone of elongation (Figure 2(f)). Despite this, these roots appeared thin and slightly brown in colour, raising the question of whether supplementing the media with auxins would produce healthier roots. Histological examination of root tips showed that IAA-induced roots con- 
sist of many smaller cells that also organized into distinct regions (Figure 2(g)). However, cells from the IAAinduced roots appeared to have a larger zone of cell division and were not elongating to produce long roots. Roots that were induced by IBA showed the best root anatomy as indicated by the presence of various distinctive regions (Figure 2(h)). Sections of root tips developed from the NAA treatment showed that each root tip consisted of many small cells organized into a condensed miniature root. The epidermal, cortical and root cap cells near the tip region appeared to be loosely packed and sloughed off prematurely (Figure 2(i)). Longitudinal sections of 2,4-D induced root tips showed thin roots with irregularly shaped elongated parenchyma cells, a poorly developed root cap, and sloughing of epidermal cells (Figure 2(j)).

\section{Discussion}

Murashige and Skoog basal medium is comprised of many different macro- and micronutrients initially optimized to the in vitro regeneration of tobacco. It is useful for the growth of most plant species, but its formulation is prepared in very high concentrations, particularly nitrogen, and may be desired in as much as a 10-fold dilution by a particular species and explant type [13]. Thus, lowering the strength of MS medium is often used in vitro culture for rooting of cuttings, as reported in "Delicious" apple, Malus domestica [14] and Ophiorrhiza prostrata, an anti-cancer drug producing plant [15]. This study further confirms that lowering the strength of MS medium was essential for inducing adventitious root formation in B. sinuspersici cuttings and that half-strength MS medium was determined to be the optimal concentration for this process.

Auxins are phytohormones critical to root growth and development. Plants use auxin gradients to promote cell division, determine cell fate, and establish environmental controls that regulate overall root development through multiple biosynthetic pathways [16]. Without the presence of exogenous auxins, in vitro root formation relies on endogenous auxin synthesized in the shoot apex and transported downwards to create an auxin gradient required for root induction [17]. This established gradient of auxin allows cells to maintain information about their growth and development past the initial signals that caused cell differentiation, while changes in the auxin gradient allow the plant to control its development [17]. These developmental changes can be induced artificially to promote root cell differentiation by adding exogenous auxins. Although root induction of cuttings was effective using hormone-free media (Figure 2(a)), auxins such as IBA induce healthier, longer, and more numerous adventitious roots. Moreover, examining the effect of different auxins on the induction and development of adventitious roots in B. sinuspersici cuttings would be resourceful for adventitious root induction experiments of indirect organogenesis-derived shoots.

Each of the auxins examined (2,4-D, IAA, IBA, and NAA) affected the in vitro induced roots differently. Medium supplemented with $1 \mathrm{mg} / \mathrm{L}$ IBA produced the longest roots and facilitated a high survival rate among plants after transplantation to soil. 2,4-D, IAA and NAA were determined to be poor rooting hormones for $B$. sinuspersici due to the formation of short, unhealthy roots and low survival rates when transplanted to soil. Studies comparing the effects all four examined auxins favoured IBA as a root induction agent in both Plumbago zeylanica [18] and Eucalyptus spp. [19]. Furthermore, root induction using IBA were also observed in African Blackwood, Dalbergia melanoxylon [20], Indian horsechestnut, Aesculusindica [21], and ponytail palm, Nolinarecurvata [22]. In general, high concentrations of auxins are required for root initiation, but may also inhibit its development [23]. It has been suggested that IBA is the most efficient auxin at inducing root growth because its longer side chain length makes it more difficult for plants to oxidize [24]. The ability of IBA to be metabolized to IAA may create a slow release to lower the concentration and allow root development to progress gradually, making it more suited to root development rather than root initiation compared to other auxins [19]. However, NAA is even more stable, and thus may be inhibitory to development due to its accumulated concentration. These results suggest that IBA has an impact on root growth by promoting and accelerating cell differentiation to form roots and increasing of rate of root growth, while 2,4-D, IAA, and NAA inhibit root development and elongation. These observations are consistent with our results showing that $B$. sinuspersici cuttings cultured on medium supplemented with IBA developed long roots and had a high survival rate upon transplanting to soil compared to those cultured on medium containing 2,4-D, IAA, or NAA.

\section{Conclusion}

In conclusion, we have developed an efficient and rapid method of propagating B. sinuspersici through cuttings. Although rooting of cuttings may be induced on hormone-free medium, half-strength MS medium containing 
IBA appeared to be the most effective auxins at inducing adventitious roots in $B$. sinuspersici cuttings and may be used to facilitate root development in vitro-derived shoots. The single-cell $\mathrm{C}_{4}$ species, Bienertia sinuspersici, can be successfully and efficiently propagated by this method.

\section{Acknowledgements}

This research was supported by the Natural Sciences and Engineering Research Council (NSERC) of Canada Research Grants and the University of Waterloo Start-Up Fund to SDXC.

\section{References}

[1] Akhani, H., Barroca, J., Koteyeva, N., Voznesenskaya, E.V., Franceschi, V.R., Edwards, G.E., Ghaffari, S.M., Stichler, W. and Ziegler, H. (2005) Bienertia sinuspersici (Chenopodiaceae): A New Species from SW Asia and Discovery of a Third Terrestrial $\mathrm{C}_{4}$ Plant without Kranz Anatomy. Systematic Botany, 30, 290-301. http://dx.doi.org/10.1600/0363644054223684

[2] Voznesenskaya, E.V., Franceschi, V.R., Kiirats, O., Artyusheva, E.G., Freitag, H. and Edwards, G.E. (2001) Proof of $\mathrm{C}_{4}$ Photosynthesis without Kranz Anatomy in Bienertia cycloptera (Chenopodiaceae). Plant Journal, 31, 649-662. http://dx.doi.org/10.1046/j.1365-313X.2002.01385.x

[3] Chuong, S.D.X., Franceschi, V.R. and Edwards, G.E. (2006) The Cytoskeleton Maintains Organelle Partitioning Required for Single-Cell $\mathrm{C}_{4}$ Photosynthesis in Chenopodiaceae Species. Plant Cell, 18, 2207-2223. http://dx.doi.org/10.1105/tpc.105.036186

[4] Kesari, V. and Krishnamacheri, A. (2007) Effect of Auxins on Adventitious Rooting from Stem Cuttings of Candidate plus Tree Pongamia pinnata (L.), a Potential Biodiesel Plant. Trees, 23, 597-604. http://dx.doi.org/10.1007/s00468-008-0304-x

[5] Thorpe, T.A. (2007) History of Plant Tissue Culture. Molecular Biotechnology, 37, 169-180. http://dx.doi.org/10.1007/s12033-007-0031-3

[6] Evan, B.R., Bali, G., Foston, M., Ragauskas, A.J., O’Neil, H.M., Shah, R., McGaughey, J., Reeves, D., Rempe, C.S. and Davison, B.H. (2015) Production of Deuterated Switchgrass by Hydroponic Cultivation. Planta, 242, $215-222$. http://dx.doi.org/10.1007/s00425-015-2298-0

[7] This, P., Lacombe, T. and Thomas, M.R. (2006) Historical Origins and Genetic Diversity of Wine Grapes. Trends in Genetics, 22, 511-519. http://dx.doi.org/10.1016/j.tig.2006.07.008

[8] Belide, S., Hac, L., Singh, S.P., Green, A.G. and Wood, C.C. (2011) Agrobacterium-Mediated Transformation of Safflower and the Efficient Recovery of Transgenic Plants via Grafting. Plant Methods, 7, 12. http://dx.doi.org/10.1186/1746-4811-7-12

[9] Jaganath, B., Subramanyam, K., Subramanian, M., Karthik, S., Elayaraja, D., Udayakumar, R., Manickavasagam, M. and Ganapathi, A. (2014) An Efficient in Planta Transformation of Jatrophacurcas (L.) and Multiplication of Transformed Plants through in Vivo Grafting. Protoplasma, 251, 591-601. http://dx.doi.org/10.1007/s00709-013-0558-z

[10] Skoog, F. and Miller, C.O. (1957) Chemical Regulation of Growth and Organ Formation in Plant Tissue Cultured in Vitro. Symposia of the Society for Experimental Biology, 11, 118-131.

[11] Rosnow, J., Offermann, S., Park, J., Okita, T.W., Tarlyn, N., Dhingra, A. and Edwards, G.E. (2011) In Vitro Culture and Regeneration of Bienertia sinuspersici (Chenopodiaceae) under Increasing Concentrations of Sodium Chloride and Carbon Dioxide. Plant Cell Reports, 30, 1541-1553. http://dx.doi.org/10.1007/s00299-011-1067-1

[12] Northmore, J.A., Zhou, V. and Chuong, S.D.X. (2012) Multiple Shoot Induction and Plant Regeneration of the SingleCell $\mathrm{C}_{4}$ Species Bienertia sinuspersici. Plant Cell, Tissue and Organ Culture, 108, 101-109. http://dx.doi.org/10.1007/s11240-011-0018-4

[13] Huang, L. and Murashige, T. (1977) Plant Tissue Culture Media: Major Constitutents, Their Preparation and Some Applications. Methods in Cell Science, 3, 539-548. http://dx.doi.org/10.1007/bf00918758

[14] Zimmerman, R.H. (1984) Rooting Apple Cultivars in Vitro: Interactions among Light, Temperature, Phloroglucinol and Auxin. Plant Cell, Tissue and Organ Culture, 3, 301-311. http://dx.doi.org/10.1007/BF00043081

[15] Martin, K.P., Zhang, C.L., Hembrom, M.E., Slater, A. and Madassery, J. (2008) Adventitious Root Induction in Ophiorrhiza prostrata: A Tool for the Production of Camptothecin (an Anticancer Drug) and Rapid Propagation. Plant Biotechnology Reports, 2, 163-169. http://dx.doi.org/10.1007/s11816-008-0057-4

[16] Overvoorde, P., Fukaki, H. and Beeckman, T. (2010) Auxin Control of Root Development. Cold Spring Harbor Perspectives in Biology, 2, a001537. http://dx.doi.org/10.1101/cshperspect.a001537

[17] Grieneisen, V.A., Xu, J., Maréem, A.F.M., Hogeweg, P. and Scheres, B. (2007) Auxin Transport Is Sufficient to Generate a Maximum and Gradient Guiding Root Growth. Nature, 449, 1008-1013. http://dx.doi.org/10.1038/nature06215 
[18] Saxena, C., Samantaray, S., Rout, G.R. and Das, P. (2000) Effect of Auxins on in Vitro Rooting of Plumbago zeylanica: Peroxidase Activity as a Marker for Root Induction. Biologia Plantarum, 43, 121-124. http://dx.doi.org/10.1023/A:1026519417080

[19] Fogaça, C.M. and Fett-Neto, A.G. (2004) Role of Auxin and Its Modulators in the Adventitious Rooting of Eucalyptus Species Differing in Recalcitrance. Plant Growth Regulation, 45, 1-10. http://dx.doi.org/10.1007/s10725-004-6547-7

[20] Amri, E., Lyaruu, H.M.V., Nyomora, A.S. and Kanyeka, Z.L. (2009) Vegetative Propagation of African Blackwood (Dalbergia melanoxylon Guill. \& Perr.): Effects of Age of Donor Plant, IBA Treatment and Cutting Position on Rooting Ability of Stem Cuttings. New Forests, 39, 183-194.

[21] Majeed, M., Khan, M.A. and Mughal, A.H. (2009) Vegetative Propagation of Aesculus indica through Stem Cuttings Treated with Plant Growth Regulators. Journal of Forest Research, 20, 171-173. http://dx.doi.org/10.1007/s11676-009-0031-1

[22] Bettaieb, T., Mhamdi, M. and Hajlaoui, I. (2008) Micropropagation of Nolina recurvata Hemsl.: $\beta$-Cyclodextrin Effects on Rooting. Science Horticulturae, 117, 366-368. http://dx.doi.org/10.1016/j.scienta.2008.05.023

[23] De Klerk, G.J., Krieken, W.V.D. and Jong, J. (1999) The Formation of Adventitious Roots: New Concepts, New Possibilities. In Vitro Cellular \& Developmental Biology-Plant, 35, 189-199. http://dx.doi.org/10.1007/s11627-999-0076-Z

[24] Fawcett, C.H., Wain, R.L. and Wightman, F. (1960) The Metabolism of 3-Indolylalkanecarboxylic Acids, and Their Amides, Nitriles and Methyl Esters in Plant Tissues. Proceedings of the Royal Society London B, 152, 231-254. http://dx.doi.org/10.1098/rspb.1960.0035 